2019 TheoLogica

An International Journal for Philosophy of Religion and Philosophical Theology

S. I. THE SON OF GOD

DOI: https://doi.org/10.14428/thl.v2i3.2283

\title{
Incarnation, Divine Timelessness, and Modality
}

\author{
EMILY PAUL \\ University of Leeds \\ ¡h08egp@leeds.ac.uk
}

\begin{abstract}
A central part of the Christian doctrine of the incarnation is that the Son of God 'becomes' incarnate. Furthermore, according to classical theism, God is timeless: He exists 'outside' of time, and His life has no temporal stages. A consequence of this 'atemporalist' view is that a timeless being cannot undergo intrinsic change - for this requires the being to be one way at one time, and a different way at a later time. How, then, can we understand the central Christian claim that the Son of God 'becomes' human? This paper examines one such explanation, drawn from a brief remark by Brian Leftow: the Word takes on flesh by exhibiting modal variation with regards to the incarnation. On this account, a timeless God 'becomes' incarnate simply due to variation across logical space: at some possible worlds $\mathrm{He}$ is incarnate and at others $\mathrm{He}$ is not. Modal variation need not, therefore, require temporality: it only requires variation across (static) possible worlds. I draw out the problems with Leftow's modal claim under the heads of Ersatzism and Genuine Modal Realism about possible worlds, respectively. I argue that in both instances, Leftow's desired crossworldly variation of the Son's incarnation cannot be achieved.
\end{abstract}

Keywords: Son of God, Incarnation, Atemporality, Modality, Divine Freedom

A central part of the Christian doctrine of the incarnation is the notion of the Son 'becoming' incarnate. The Creed of Nicea states that 'because of us men and because of our salvation [The Son] came down and became incarnate, becoming man' (Kelly 1960, 216 italics mine). The Son did so, according to Christian belief, as a response to human sin. His prerogative was to remain unincarnate, but nevertheless He 'took on flesh' as a sacrifice for humankind. ${ }^{1}$ The Son's sharing

\footnotetext{
${ }^{1}$ Henceforth, I'll refer to God (including the Son of God) using the male pronoun, for ease of consistency with the many quotations that I'll draw upon. However, I (of course) want to remain neutral regarding God's gender, or lack thereof.
} 
our human condition has important soteriological features, in that His sacrifice paved the way for the rest of humanity to achieve salvation themselves. By living as a human, spreading the word about God's existence, and suffering and dying on the cross as a human, the Son restored humankind's relationship with God. This made it possible (or so it's believed) for all mere mortals to achieve salvation. Importantly, this salvation is only thought to be possible because the Son truly became human: because divinity and humanity genuinely united into one single person. It can't be that the Son merely appeared to become the human Jesus, whilst really remaining only divine, lest His sacrifice be diminished and our salvation be impossible. R. T. Mullins writes if the incarnation is to be meaningful we must know that God Himself has become incarnate' $(2016,178)$.

I'm interested in the extent to which this central and indispensable Christian belief about the Son of God can be upheld in conjunction with the doctrine of divine timelessness. This is the classical view of God's relation to time, which deems Him to be atemporal: He exists 'outside' of time and views all events in time as if in one 'simultaneous present'. There are no temporal stages in an atemporal God's life. Recently, Mullins has provided a clear and comprehensive definition of atemporality: 'God is timeless if and only if God exists (i) without beginning, (ii) without end, and (iii) without succession. To say that God exists without succession means that God does not do one thing, and then another' $(2016, \mathrm{xvi}){ }^{2} \mathrm{I}^{\prime}$ 'll henceforth refer to proponents of this view of God's relation to time as 'atemporalists'. ${ }^{3}$

\footnotetext{
2 This is in contrast with divine temporalism, whereby God He exists 'within' time. Mullins provides the following conditions which he deems to be a necessary and sufficient guarantee of temporality: 'God is temporal if and only if God exists (i) without beginning, (ii) without end, and (iii) with succession. The life of a temporal God is characterised by a succession of moments' (2016, xvi). It's important to note that only the final attribute has changed here from Mullins' definition of a timeless God: whether or not God's life comprises a succession of moments is what distinguishes a temporal God from a timeless one.

${ }^{3}$ Importantly, I'm considering the compatibility of incarnation and The Son's atemporality. The question remains, then, whether the (a)temporal mode of the Son's existence can be straightforwardly applied to the other two members of the Trinity. Thomas Senor argues that if one member of the Godhead possesses a particular relation to time, all members of the Godhead exist in that same relation (1990, 159-61). Mullins also suggests that it's part of Arian heresy to attribute timelessness to the Father and temporality to the Son. He says that Arians 'had no qualms denying divine timelessness...[to] the Son. On their understanding, only the Father enjoys these particular divine attributes because only the Father is the one true God, whereas the Son is a lesser divine being' $(2016,162)$. I'm certainly inclined to agree with Senor and Mullins, for I feel that if different members of the Trinity exist in different relations to time, this is driving too much of a wedge between their respective existences. It also seems to threaten their shared essence. I don't have the space to argue for this conclusion here, however. I'll simply venture that all members of the Trinity exist in the same relation to time, and hope that
} 
An important consequence of atemporalism, for our purposes, is that a timeless being can't undergo intrinsic change - for this requires something to be one way at one time, and a different way at a later time. Thomas Senor argues that in order for the Son to 'take on' human nature, He must be mutable, and so, temporal. He says:

The question presently before us is whether one's taking on $X$ entails that in virtue of assuming $X$, one has changed. It certainly sounds to my ear as if the entailment holds. I can't see how, if the Second Person of the Trinity is perfectly immutable (and so, atemporal), he could 'take on' anything. What he has, he has; what he has not, he has not $(1990,158-9)$.

How, then, is the atemporalist to understand the central Christian claim that the Son of God 'becomes' human, if not by virtue of an intrinsic change? Given that the incarnation is a fundamental and indispensable aspect of Christianity, a suitable metaphysical explanation is required. There have recently been several attempts to provide just such an account, most of which appeal to some sort of extrinsic change on the part of God the Son, when a human body and soul join to Him, forming a composite. These are a form of compositionalist accounts of the incarnation, where Christ is comprised of various parts: 'a compound of qualitatively and numerically different constituents: a divine mind, a human body, and, on some models, a human mind as well' (Marmodoro and Hill 2010, 469). Distinguishing between these different parts of Christ enables atemporalists to appeal to an intrinsic change in something other than the Son Himself. The intrinsic change presumably takes place in the created order, when the human parts of the composite come into existence. ${ }^{4}$ This in turn allows the divine part of the composite, the Son, to change only extrinsically when He becomes incarnate..$^{5}$ Because this change is only extrinsic, it's argued, the Son needn't be temporal.

The focus in this paper will be on elucidating an alternative, and hitherto unexplored, (potential) option for the atemporalist seeking to understand the claim that the Son of God 'becomes' incarnate. It's drawn from a very brief

this point is relatively uncontentious. At the very least, denying it would leave one facing many charges of unorthodox Trinitarianism.

${ }^{4}$ It can't be the human components of the composite themselves that undergo intrinsic change, because 'coming into existence' isn't a change that any thing can undergo. In order to change intrinsically, the subject of the change must exist both before and after the change, and yet if something comes into existence it doesn't, by definition, exist prior to this event.

${ }^{5}$ See, for example, Hill (2012, 26-9), and Leftow (2002). 
remark by Brian Leftow in his paper 'A timeless God incarnate' (2002, 273299). ${ }^{6}$ I call it Leftow's 'modal claim,' and it's as follows:

The import of the 'taking on' [flesh] claim on God's side is modal, not temporal. That God took on flesh does not entail that he changed. It entails only that he could have been God without being incarnate, and that if he could have refrained from becoming incarnate, he could have not had a body. Here I simply bat the ball back onto the temporalist's side of the net: why isn't this enough to make orthodox sense of the claim that God the Son took on flesh? $(2002,299)$

Arguably, atemporalists could adopt Leftow's claim as a way of explaining how the Son became incarnate without being subject to the passage of time. If we read 'became' or 'taking on' in a modal sense, the Word becomes flesh in that in this world He takes on human form, but in other possible worlds He doesn't. Understanding Leftow's claim in terms of possible worlds tells us that there are possible worlds that are exactly the same as ours, except that they lack a divine incarnation, meaning that they also presumably lack atonement for any sin that takes place there. ${ }^{7}$ According to Leftow, we therefore have variation across logical space regarding the incarnation. This is an independently important claim to uphold, for it helps to emphasise the supererogatory sacrifice that the Son made for us. The difference is that Leftow needs this variation in order for his argument to go through: he seems to think that instead of intrinsic change, this cross-worldly variation regarding the incarnation is all that we need to make sense of a timeless Son 'becoming' incarnate.

The focus of this paper will be to give Leftow's modal claim the scrutiny that it deserves. I'll consider different ways of cashing it out, arguing that it doesn't in fact leave us with Leftow's desired modal variation, and so it can't be appealed to as a means of explaining a timeless God becoming incarnate. A further unwelcome consequence falls out of this result: divine libertarian freedom is impinged upon. In section 1, I present an argument that Leftow's claim doesn't give us modal variation, and respond (sections 2-3) to potential objections to the weakest premises. Sections 4 and 5 consider the problematic implications of Leftow's argument for ersatzism and genuine modal realism about possible worlds, respectively. I conclude that, in light of these arguments,

\footnotetext{
${ }^{6}$ Leftow also defends the compositionalist account of extrinsic change (mentioned above) in the same paper. His modal claim is altogether distinct from this, however-and is mentioned only in passing.

7 Unless there are other ways to achieve atonement besides incarnation. This will be discussed in section 3 .
} 
atemporalists can't appeal to modal variation as a way that the Son becomes incarnate, without taking on board serious dialectical tensions.

Before we venture into these specifics, though, it's tempting to object that Leftow's modal claim is a non-starter, because it's simply too weak to do the work that we need. Surely, even if we can make sense of the Son not taking on a body in other possible worlds, this claim isn't substantial enough for us to be able to say that He 'became' incarnate? The incarnation takes place in the actual world - the Word becomes flesh. Surely, then, there must be a sense in which the Son takes on flesh relative only to the history of this world, regardless of what happens at other worlds? Not wanting to beg the question against Leftow's modal account, I'll grant for the sake of argument that we can make sense of something 'becoming' something else due solely to modal variation. My objection to Leftow will instead lie in revealing the unwelcome tensions and consequences that follow once we apply his claim to particular understandings of modality.

It's important to emphasise the sense of the Son's libertarian freedom that's implicit in Leftow's claim. Libertarian freedom rests on a form of incompatibilism: the view that our freedom is incompatible with our actions being causally determined. It's also commonly thought to require alternative possibilities for action. So, I'm free to do $x$ iff at the time of performing $x$, it's possible that I refrain from doing so. For instance, I'm free to get a puppy iff, at the time of doing so, it's possible that I refrain. ${ }^{8}$ There must be alternative possibilities available to me, such as changing my mind and going home empty-handed, or getting a hamster instead. Leftow seems to require that the Son be free in this libertarian sense, because he stresses in the passage above that God 'could have refrained' from being incarnate. It must be possible that He refrain from taking on a body. ${ }^{9}$ Leftow also endorses libertarian divine

\footnotetext{
${ }^{8}$ See, e.g. Diekemper $(2012,47-8)$.

${ }_{9}$ Some compatibilists might object here that there's nothing preventing them from accepting this appeal to alternative possibilities. David Lewis, for example, stresses that even in the face of a causally determined universe, it would be the case that I'm able to act otherwise than the way in which I in fact act. He argues that I'm able to do otherwise in the sense that if I do something which it was determined that I'd not do, then some law of nature would have been broken (Lewis 1981, 122-29). However, even if the universe is causally determined, this isn't something that God's freedom would have to be rendered compatible with, given that He created the universe ex nihilo (more on this anon). Moreover, I'm assuming here that God is atemporal, which makes it still easier to see how He's removed from the (determined) causal unfoldings of the universe. I therefore contend that, whilst compatibilists might be able to help themselves to the principle of alternative possibilities regarding human freedom, this isn't something that makes sense in the case of divine freedom. It would be a mistake to allege that the determined unfolding of events in the universe - that God created and is causally and temporally isolated
} 
freedom and the principle of alternative possibilities elsewhere. He says in a recent paper that 'God acts freely, in a robust sense which implies He could have acted otherwise' (Leftow 2016, 47). He reads this possibility of refraining in a libertarian sense (Leftow forthcoming). This is evidently an important reason why, for Leftow, there must be variation across possible worlds regarding incarnations. I'll now present an argument that Leftow's claim, when cashed out, doesn't give us his desired variation across possible worlds.

\section{Leftow's Claim doesn't give us Modal Variation}

(P1) The Son takes on a body in the actual world to redeem us from sin, and because of His omnibenevolence. ${ }^{10}$

(P2) There are other possible worlds that contain as much/more sin than ours.

(P3) If the Son takes on a body in no other possible worlds, then there are possible worlds that contain as much, or more, sin than ours, in which there are no incarnations.

(P4) There are no ways, besides incarnation, that salvation can be achieved.

(P5) If God becomes incarnate at a world $w$, but not at other worlds with as much or more sin than $w$, then He isn't omnibenevolent.

(C1) (From P1, P3, P4 \& P5) If the Son doesn't take on a body in all the possible worlds with as much/more sin than ours, then He isn't omnibenevolent.

(P6) God is omnibenevolent.

(C2) (From C1 \& P5 via modus tollens) The Son takes on a body in all the possible worlds with as much/more sin than ours.

(C3) (From C2) Quantifying over all worlds with as much or more sin than ours, the Son necessarily takes on a body.

(P1) states God's omnibenevolence, and the purpose of the incarnation being atonement. (P2) follows from the contingency of sin, together with the belief that humans have been given free will. We can suppose that for every logically possible human, and every logically possible action they might carry out, there's a possible world to represent this. Many of these worlds will be ones

\footnotetext{
from-is something that His freedom needs to be made compatible with. However, a different version of a compatibilist divine freedom will be discussed in section 4 .

${ }^{10}$ Henceforth, I'll be assuming that ' $\sin$ ' is equivalent to 'evil,' so long as evil is understood as being actively caused by humankind, or by the inhabitants of the particular world in question.
} 
containing more sin than this one. For instance, there's a possible world where I kick puppies instead of studying philosophy. This world (assuming it's otherwise the same as ours) seems - quite uncontentiously - to be a more sinful world than ours. (P3) follows if we accept (P2). As I've mentioned, the only way that atonement could have been achieved was for the Son to truly become one of us in order to restore humankind's relationship with God, and this is represented here by (P4). The basis for (P5) is God's omnibenevolence being such that He wouldn't permit worlds with the same amount, or more, sin than our own to not be atoned, whilst nevertheless becoming incarnate in our world. If He did permit this, it would make His decision to be incarnate in our world an arbitrary one, so not one that, I submit, we'd wish to attribute to a perfectly loving and rational God. In fact, it would be possible for a more loving being to exist, who is incarnate in these other worlds, and makes reasoned, fair decisions to boot. (P6) is a requirement of classical theism. We derive (C2) from (C1) and (P6) via modus tollens. (C3) then follows from (C2) because at all of the worlds with as much or more sin than ours, the Son takes on a body, which on a reductive account of modality is just what it means to say that taking on a body is (quantifying over these worlds) necessary. If this argument is sound, Leftow's modal claim can't explain how a timeless God 'becomes' incarnate. I'll now consider, and respond to, some potential objections.

\section{Concerning 'Relevantly Similar' Worlds}

An initial objection raises its head, regarding my quantifying only over the worlds with as much, or more, sin that our own. (C2) claims that all of the worlds 'with as much or more sin than ours' contain the Son taking on a body. It might be objected that Leftow's desired modal variation is in fact achieved, because the scope of (C2) is too narrow. After all, it doesn't mention the worlds containing less sin than our own, where no incarnations are required. It's these (incarnation free) worlds that would generate modal variation, the argument would go. In response to this, I maintain that we must restrict our scope to closer, relevantly similar worlds to our own if we wish to generate a sufficiently substantial sense in which the Son 'could have refrained' from being incarnate. I contend that the worlds relevant to Leftow's argument must be relevantly similar in (at least) the following way: they must contain the same amount, or more, sin than our own. ${ }^{11}$

${ }_{11}$ Perhaps in order to count as 'relevantly similar,' the worlds in question also ought to contain inhabitants who are free in the same way that we are. This is in light of discussion that will follow in section 4 . 
This qualification isn't an ad hoc addendum, but has independent motivation due to the aforementioned emphasis that Leftow places upon the libertarian freedom of the Son. Importantly, when scrutinising our libertarian freedom, we look to the closest possible worlds to examine whether it's possible for us to refrain from acting in a certain way. For instance, if I want to know whether it's possible for me to refrain from getting a puppy, I look to the closest possible worlds where, for instance, my history up until now, my living situation, financial situation and love of animals are all the same as at this world - and see whether or not these worlds contain my obtaining a puppy. I'm not concerned with the distant worlds in which, say, I actively despise dogs, or dogs don't even exist. Likewise, if we want to account (as Leftow evidently does) for a genuine sense of the Son's libertarian freedom to take on flesh, we must look to the relevantly similar worlds, and see whether He's incarnate there. Although only one incarnation-free world is needed for Leftow's claim to go through, this world must be one that contains the same amount, or more, sin than ours, because of the emphasis being placed on the Son's free decision to respond to sin. Insofar as the incarnation is a response to sin, then, our attention ought not to be occupied by distant worlds with less sin than our own. We should restrict it only to the worlds with as much, or more sin than ours. At all of these, I've argued, the Son is incarnate.

\section{Potential responses}

Perhaps the most contentious premise is (P4). Leftow might object to it for several different reasons. Firstly, he could argue that the Son didn't need to respond to sin specifically by taking on a body. That is, there could be other ways in which Atonement could be achieved, such that God can remain perfectly good and loving even if He doesn't respond to sin by becoming incarnate. A species of this objection might be the case of a possible world whose inhabitants aren't embodied. ${ }^{12}$ If this were the case, the argument would go, then (P4) is false, because the Son wouldn't need to take on a body in order to atone for the sins of that world's inhabitants. More broadly, even in cases where our counterparts are embodied, there could simply be other ways (ways that we can't begin to comprehend) in which the Son could atone for our sins, besides taking on flesh.

12 Supposing, of course, that these disembodied beings could be our counterparts. They would need to be such in order for this possible world to count as sufficiently close to our own, to generate the desired sense in which the Son 'could have refrained' from being incarnate. After all, the more distant the possible worlds that we use to support this claim, the less we're able to take account of the Son's free decision to take on flesh. 
I think it would still be possible to retain the spirit of my argument if, in response to this objection, I broadened my claims so that instead of referring to physical incarnations, or the taking on of a body, I appealed instead to any soteriological gesture on behalf of the Son. If I plugged something like this into my argument, then its wider scope would generate the (still, for Leftow, unwelcome) result that at all worlds with as much, or more, sin that ours, the Son engages in some sort of soteriological action. A similar conclusion to (C3) would be generated, and would be something like: 'quantifying over all worlds with as much or more sin than ours, the Son necessarily acts to redeem us from $\sin ^{\prime}$. However, any divine action to save us from sin, I'd argue, ought to be freely chosen - and, therefore, contingent. In this broader context, it would thus also need to exhibit modal variation. I therefore contend that my argument can be widened in such a way that it creates a problem for Leftow's modal claim even when we factor in possible worlds containing incorporeal inhabitants or alternative forms of Atonement. This would additionally keep us in line with Leftow's recent suggestion that:

Christians believe that their salvation is an act of free grace: that God need not have sent Christ to die for them. Even those who think that God's love guaranteed His doing something to save us may think that He need not have done so by sending Christ $(2017,152)$.

Again, it could be responded here that even if it wasn't specifically incarnation that was necessary to redeem us from our sins, God (being omnibenevolent), would still have responded to sin with some sort of soteriological gesture. This would be the case in every world with as much, or more, sin than our own, it could be argued, otherwise we can imagine a more loving (and less arbitrary being) who would treat all worlds fairly. I'll henceforth leave (P4) as it is, referring specifically to incarnation as a response to sin, but if one prefers, one can imagine my argument widened in the way suggested above.

Changing tack slightly, Leftow might object to (P5) by claiming that the Son can remain omnibenevolent in spite of not becoming incarnate (or, in line with the above, wider argument: in spite of not engaging in any soteriological gesture) at the worlds with as much, or more, sin than a world $w$ - in this case, our world. It seems strange, after all, to insist that there's a precise level of sin, at which point God must personally intervene by taking on human form. Leftow could appeal to divine mystery, and reject the assumption that God's omnibenevolence necessitates an incarnation whenever there's a world as sinful as our own. At any rate, perhaps there's far more to be considered in what makes for the 'best' world besides the level, or quantity, of sin, and God considers this when surveying worlds and their need for atonement. We, on the 
other hand, have no real insight into God's reasons. On this account, Leftow could argue that it merely seems arbitrary and reasonless to us if there are two worlds with equal levels of sin, but God is only incarnate at one: in fact, our omniscient God has (timelessly) surveyed both worlds, and taken everything into account, and made a fully-informed decision about what's best for each of these worlds.

In response to this, I grant that it's possible that God is taking far more into account than levels of sin when considering whether or not to be incarnate in various worlds. However, the incarnation is of course a response to sin, and I'm therefore confident that sin must at least be an important factor in world rankings. I venture that the burden of proof is on theists in Leftow's camp to demonstrate what else exactly could be considered in making for the best possible world. Might it be the number of people (or other inhabitants) that exist in a world, for instance? Or, might it be to do with the ubiquity of sin within any world in question? Arguments along these lines would need additional support. Alternatively, if Leftow were to explain God's decision to be incarnate by appeal to divine mystery, then this is less satisfying given that I'm attempting to elucidate metaphysical issues - namely, how a timeless Son can become incarnate.

There's a related objection to (P5) in the vicinity, which I consider more troubling. Leftow might object that it's crude to assume that sin can in fact be measured in the way that I'm suggesting. If this were the case my argument wouldn't stand, because one wouldn't be able to compare levels of sin across worlds. After all, it seems very difficult to imagine that there's some sort of 'unit' by which we could compare, say, the sin involved in a mass murder with the sin involved in mass torture. If this were the case, (P2) could also be denied, and my overall conclusion would no longer follow. Nonetheless, given that God did respond to sin in the actual world by taking on human form, there must have been something that made Him think that this response was required, lest the response be arbitrary. Furthermore, implicit in Leftow's modal claim is the assumption that God responded to sin in at least one world, but not in others. It's difficult to see how these responses (or non-responses) can be motivated without some consideration of levels of sin at the worlds in question. I therefore contend that the burden of proof is again on Leftow to demonstrate why this consideration of sin can't be applied to other worlds, and compared across worlds.

Having considered these potential objections, I maintain that, at the very least, there are serious tensions embedded in Leftow's modal claim. We're unable to generate Leftow's desired conception of 'becoming' incarnate, 
because we find that the Son takes on a body in all of the relevantly similar worlds to our own ('relevantly similar' regarding their amounts of $\sin$ ). ${ }^{13}$ This is problematic for two reasons. Firstly, we can't make sense of modal variation regarding the incarnation, which limits the lines of argument at the atemporalist's disposal for explaining the Son 'becoming' incarnate. Secondly, the modal claim impinges upon the Son's libertarian freedom, because no relevantly similar possible worlds contain His refraining from incarnation. Divine libertarian freedom is evidently something that Leftow would want to preserve, and we've seen evidence of this above. In fact, I don't think it would be presumptuous to say that most theists would want to preserve this. They'd want to maintain that God is the freest of all beings, whose freedom doesn't need to be rendered compatible with, for instance, His causally determined actions, in order to count as freedom. Moreover, if the Son isn't free to do anything other than take on flesh, then it also presumably makes little sense for us to praise or thank Him for doing so - since it emerges that it wasn't a choice that $\mathrm{He}$ was responsible for making. There are some differences in the implications (and potential responses to) this argument, depending upon how we understand these possible worlds - so I'll now further develop and defend my argument under the heads of ersatzism and genuine modal realism about possible worlds, respectively.

\section{Ersatz Modal Realism (EMR)}

The possible worlds that Leftow invokes in his modal claim could be understood in an ersatzist sense, whereby they're 'surrogates' for the actual world, but don't concretely exist. Rather, they're more like maximally consistent states of affairs that form total 'conditions' that a concrete world could be in. ${ }^{14}$ Ersatzists are usually actualists: they're committed to the view that everything that exists actually exists. The contents of all possible worlds actually (but non-

\footnotetext{
${ }^{13}$ It will not do to respond here that there is a possible world much like ours in the amount and distribution of sin, where the Son does not become incarnate because instead the Holy Spirit does so. If this were the case, it would indeed be possible for the Son to refrain from becoming incarnate. Thank you to an anonymous referee for raising this objection. I am being specific in my referring to the Son, but the Son is of course (on an orthodox understanding of the Trinity) simply God, as are the Father and Holy Spirit. If there is a possible world where the Son refrains from becoming incarnate, but the Holy Spirit does become incarnate, it remains the case that God becomes incarnate at this world - and at all words with as much or more sin than our own. This latter result, I would argue, is equally problematic.

${ }^{14}$ I don't think it matters for my account whether I sketch the ersatzist view with regards to possible worlds being states of affairs, or anything else, such as propositions or sets of propositions: one can simply substitute in one's favoured interpretation.
} 
concretely) exist, because they're constructed from things that themselves actually exist. Ersatzists are therefore still modal realists, of a certain stripe. The actual world is the only world that happens to obtain, on EMR. It therefore has a special status: it's actualised, because it's the way that things in fact are. I'll defend the view that if we understand Leftow's modal claim as an ersatzist would, we can't achieve the desired variation across worlds.

Ersatzists would read (P1) in the above argument as the Son taking on a body in the actual world - which is the only world that in fact obtains. Relatedly, Michael Almeida suggests that, because with EMR (and unlike with genuine modal realism) it's impossible to actualise more than one world, 'theists in the Leibnizian tradition are committed to the unlikely proposition that the actual world, with all of its evil, is as good as any other actualisable world' $(2011,1)$. Given divine omnibenevolence (P6), I venture that $\mathrm{He}^{\prime} \mathrm{d}$ desire to actualise the world containing the least amount of sin possible. Ersatzists ought therefore to assume that God has actualised, or created, the best of all possible worlds: so all of the others will contain more (or the same amount of) sin than our own. ${ }^{15}$

The ersatzist will thus interpret (P2) as being potentially even stronger than it first appeared, because all possible worlds will contain as much, or more, sin than our own. Any worlds containing less sin than our own are impossible, for otherwise they would have been actualised. This is perhaps because less sin

15 Robert Adams (1972, 317-332) disputes the assumption that God created the best possible world. He says that God isn't blameworthy if He creates a world that's less than the best, with the caveat that there be no creature in it so miserable that it'd be better had it not existed. Adams says that God hasn't wronged anybody in creating this world, because the creatures in the other worlds don't exist, and merely possible beings don't have rights. An important part of Adams's argument is that God's grace (defined as the disposition to love independently of the merits of persons (ibid., 324)), means that He has no reason to love the inhabitants of one world more than any other. If this were true, then the actual world might not be the best of all possible worlds, and there could indeed be others that contain less sin and so need no divine incarnations. However, I follow William Rowe (2004) in objecting that Adams has merely shown that God isn't morally obliged to create the best world that He can. Rowe argues that this can be true and it still be the case that God's perfect goodness renders it necessary that He create the best possible world. Rowe argues that if God didn't create the best world that He could, then He wouldn't be perfectly good, because it would be possible for a more perfect being to exist. Even though creating the best was a supererogatory act (and hence, not one that God was obliged to carry out), some other morally better being could possibly create the best world, and God would no longer be the most perfect being as a matter of necessity. Rowe adds that if God has a reason for picking a world to actualise, it wouldn't have anything to do with grace as defined by Adams, because God wouldn't be able to select any worlds at all if He were only judging based on loving independently of merit. Even if one is convinced by Adams, however, I argued in section 2 that other worlds with less sin and no incarnations aren't sufficient to generate Leftow's modal variation, because they're not close enough to be relevant to our considerations. 
would generate a contradiction in all of the 'maximal consistent sentences' (or similar) that are ersatzist possible worlds. For the ersatzist, (C3) therefore wouldn't merely mean that all of the worlds with as much, or more, sin than our own contain divine incarnations - but that all other possible worlds contain divine incarnations. ${ }^{16}$ If this is so, we wouldn't even need the justification given in section 2 for appealing only to 'relevantly similar' worlds. This is because all worlds would be relevantly similar in the required sense - they' $\mathrm{d}$ all contain as much, or more, sin than our own. There would then be no sense in which we can derive Leftow's desired modal variation. This is also problematic for the Son's freedom, because there are absolutely no worlds where $\mathrm{He}^{\prime}$ s not incarnate, and so no sense in which He could have refrained from being so. Because the best (and so, actualised), possible world contains so much sin that the Son is incarnate in it, all other (less good) worlds must contain incarnations too, in response to the amounts of sin that exist there. The Son's being incarnate in the world He actualised therefore necessitates His being incarnate at all other worlds.

One line of response here might be to maintain that the best world isn't simply the world containing the least amount of sin. Rather, it's the world with the least amount of sin, together with a sufficient level of human free will. ${ }^{17}$ If this can be granted, then it's not so clear that all other worlds must contain more sin than this one - nor, therefore, is it clear that they must contain a divine incarnation. I'm inclined to agree that a sufficient sense of human free will is an important requirement of the best possible world. However, I maintain that this has no bearing on the fact that this world (the best world) has been actualised. All other worlds will contain either more sin (together with human free will) or less sin (without a sufficient sense of human free will). The former worlds will contain divine incarnations as a response to sin and so won't help Leftow with his desired modal variation. The latter worlds, because they lack a sufficient sense of human free will, are far too distant to be relevant to this argument,

${ }^{16}$ It might be objected that not all worlds contain divine incarnations, because there are some possible worlds with no created life in them at all. I'd respond that equally, these worlds contain no sin either, and (in light of discussion in section 2), simply aren't close enough to ours to count as 'relevantly similar.' Leftow would surely want the sense in which God 'could have refrained' from being incarnate to be more robust than this. That is, we want to be able to say that God 'could have refrained' from being incarnate because some inhabited worlds with free creatures don't contain divine incarnations. This is the only way that we could generate the contingent nature of the Son's sacrifice. It doesn't seem very substantial to say that the Son needn't have taken on flesh because He's not incarnate at some uninhabited worlds where the question of salvation is irrelevant.

17 This response is a species of the objection discussed in section 3 . The objection was that there's more to be considered in what makes for the 'best' possible world besides the amount of sin that exists there. 
because to say that the Son refrained from being incarnate in worlds where humans aren't even free to sin in the first place isn't to say very much at all. We don't generate a substantial sense in which the Son 'could have refrained' from being incarnate if we need to appeal to worlds which contain similar levels of sin, but unfree inhabitants. Rather, when evaluating whether it's possible that God could have refrained from being incarnate, we must look to the relevantly similar worlds. Although what's meant by 'relevantly similar' is arguably not crystal clear, I think it's safe to say that worlds containing unfree inhabitants are definitely not ones that should factor into our calculations.

An alternative response might come from the compatibilist about divine freedom. It could be maintained that in spite of there being no possible worlds that lack divine incarnations, we can still consider the Son to be free. Moreover, the compatibilist might argue that we can still make sense of the fact that the Son 'could have refrained' from being incarnate. This could be cashed out in terms of the Son (being omnipotent) having the power to refrain from being incarnate at every possible world, even if He doesn't in fact refrain from this at any. Helen Beebee discusses a version of this compatibilist response to the principle of alternative possibilities, which is to provide a 'conditional analysis' of claims about our freedom. For instance: 'to say that I was able to do $X$, even though I did not in fact do so, is just to say that, had I chosen, or decided, or wanted to do $X$, I would have done it' $(2003,259)$. This is a variant of the Lewisian response discussed earlier. In the case of an omnipotent God, therefore, it could hardly be denied that, had He chosen or decided not to be incarnate in any world, He'd of course have so refrained. As was mentioned above, this wouldn't be compatibilism in the sense that we're used to with ordinary humans, where free will is taken to be compatible with a causally determined universe. This is because in the divine case the determined universe would itself be (freely) created ex nihilo by God. Therefore, to be a compatibilist about divine freedom would be to say (something like) God is free to do $x$ 'provided nothing outside of him determines him to [do $x$ ]' (Rowe \& HowardSnyder 2008). This is spelled out a little more by Thomas Talbott, who says:

Even when God acts from an inner necessity, he remains the agent cause of his actions in just this sense: Each of them reflects his own perfectly rational judgement concerning the best course of action; none of them is the product of sufficient causes external to himself; and none of them is even partially a matter of random chance $(2009,378)$.

The common thread here appears to be that God is free because nothing external to Himself determines His action. This account could therefore be said to be compatibilist because God's freedom is deemed compatible with His nature. For 
instance, God may have no option to refrain from being incarnate when we factor in His omnibenevolent nature, but He's still free with respect to this action - because nothing external to Himself causes the incarnation to be brought about. The compatibilist could therefore appeal to this understanding of divine freedom and maintain that God 'could have refrained' from becoming incarnate because He possesses the ability to refrain, and nothing external to His nature causes Him to be incarnate. His nature might ensure that He desires to sacrifice His divine prerogative and be incarnate, but had He not wanted to do so, He of course wouldn't have. It seems that this sort of compatibilism is maintaining that divine freedom is compatible with something like 'rational' determinism - 'the determination of what the agent does by the best reasons' (Steward 2015, 68). Helen Steward observes that this is altogether different from compatibilism in the ordinary case, where human freedom is reckoned compatible with causal determinism (ibid., 69).

I nevertheless can't make sense of the compatibilist's claim about ability without relying on a modal understanding of what it means. As I see it, if the compatibilist claim is to go through, there must be a possible world in which God decides not to be incarnate, and so isn't incarnate. For instance, the Son was able to refrain from being incarnate iff there's a possible world in which He decides against taking on flesh. Possible worlds, after all, represent the entirety of logical space, so if there's no possible world in which God refrains from being incarnate, we can't say (as Leftow desires) that God 'could have refrained' from being incarnate. However, whether there are any possible worlds that don't contain incarnations is of course exactly what's up for grabs in this discussion. Therefore, whether or not the compatibilist's argument has any traction depends on how much you're convinced by the argument that follows in this paper. There is, however, a great deal more debate to be had in this area.

Notwithstanding my previous worry, I think that most theists would wish to avoid compatibilist accounts of God's freedom: they wouldn't be happy to accept that God's freedom needs to be rendered compatible with, for instance, His causally determined actions or His nature, given that He ought to be the freest possible being. This would also be an unwelcome result for Leftow himself: we've seen that he's argued elsewhere for incompatibilism regarding divine freedom. As long as Leftow is committed to his modal claim, however, a compatibilist understanding of divine freedom looks to me like His only option.

An alternative response from Leftow might be that there are in fact worlds that lack incarnations, and this is why these particular worlds aren't actualised, because - all things being equal - worlds with an opportunity for atonement are preferable to worlds without this opportunity. If this were the case, Leftow's modal claim would go through, together with libertarian divine freedom. However, this option isn't available given the indispensable assumption that 
God is necessarily omnibenevolent. To grant that some worlds with as much, or more, sin than our own don't contain divine incarnations is in effect suggesting that the Son's decision to be incarnate in our world is an arbitrary, reasonless one. It also suggests the possibility of a more loving being existing, who is incarnate at these worlds. Furthermore, it's important to note that these other worlds might have been actualised, and if they had obtained, the Son (being omnibenevolent), would be incarnate in them - which is just what it means to say that the Son is incarnate at these other worlds. ${ }^{18}$

I therefore conclude that if we interpret Leftow's argument as an ersatzist would, we're unable to achieve Leftow's desired variation across worlds. In fact, it emerges that there are no worlds in which the Son isn't incarnate. I'll now consider whether genuine modal realists have an ontology that's any better for upholding Leftow's modal claim.

\section{Genuine Modal Realism (GMR)}

$G M R$, like $E M R$, is a reductive theory of possibility and necessity, so, for instance, something is necessary if it exists in every possible world. David Lewis calls our world the 'actual' world, but only because it's the world where we happen to find ourselves, not because it's any more real than the other possible worlds $(1986,92)$. In fact, the other possible worlds are no different in kind from the actual world, and all worlds concretely exist. For Lewis, 'actual' functions as an indexical term, just like 'here' or 'there.' Inhabitants of other possible worlds will likewise correctly call their own world 'actual,' so everybody in logical space can say 'the actual world is the world in which I'm located,' and be speaking the truth. According to $G M R$, for every way that a world could be, there's a world that is that way (ibid., 2), and these worlds are concrete, maximal sums of spatio-temporally related individuals (ibid., 74). There are no spatio-temporal connections between worlds, so nothing that exists at this world can also exist at another world - lest the worlds in question not be distinct after all. Instead, we (and other members of worlds) have counterparts at other possible worlds, and our counterparts resemble us in important ways 'in content and context' $(1968,114)$. We might say, for instance, that it's contingent that yellow is my favourite colour in virtue of my having a counterpart at

\footnotetext{
18 Unless, of course, the atemporalist maintains that all other worlds are impossible, given God's omnibenevolence ensuring that He'll only ever create the best possible world. This would be to endorse modal collapse: there's only one world that God could have created, given His omnibenevolence, and thus the actual world is the only possible world. If Leftow were to take this line, however, he'd be throwing the baby out with the bath water, because if all other worlds were impossible his modal claim wouldn't even get off the ground.
} 
another world, whose favourite colour is blue. This counterpart resembles me in other ways that are sufficient for her being my counterpart - she might, for instance, have the same genetic make-up, the same parents (or at least, counterparts of my parents), and the same life story as I have in this world. ${ }^{19}$

So, how would someone who's both a theist and a genuine modal realist make sense of my argument responding to Leftow? Some noteworthy specifics are that she'd read (P2) particularly strongly, because for her these other worlds containing as much, or more, sin than our own, are real, concretely existing worlds. I venture that (P5) remains strong: if there are concretely existing worlds containing as much, or more, sin than our own, then the Son ought to care about them just as much as He cares about ours. Otherwise, we'd not be able to put the 'omni' in 'omnibenevolent' when describing God. Almeida endorses this when he says, whilst discussing theistic GMR, 'the suffering of other concrete universes is no less genuine than the suffering in our universe. We perhaps have special obligations to our worldmates. But certainly God's concern is with the multiverse as a whole' $(2011,10)$. (P6) is, once again, an indispensable requirement of theism, and so the conclusion is again generated that the Son takes on a body in all of the worlds with as much, or more, sin than ours. Before considering more specific consequences of this argument for genuine modal realists, I'll examine the possibility that their claim doesn't even get off the ground, because we can't make sense of timeless existence ' $a t^{\prime}$ any world at all.

\subsection{Timeless existence 'at' every world?}

Paul Sheehy has argued that if God is atemporal, He can't exist at any genuine modal realist worlds. This is because to exist at any one world is to exist within the confines of space and time. Indeed, the spatio-temporal separation of worlds is a crucial part of Lewis's account. This leads Sheehy to suggest that, for $G M R$, 'there can be no God at the actual world or counterparts at each of the other worlds' $(2006,318)$. The worry would mean that a timeless God can't be necessary, because necessary existence just is existence at every possible world. Importantly, ersatzists don't face this worry, because their possible worlds are

19 These suggested traits are just examples - I'm not arguing that their possession is essential for qualifying as one's counterpart. I think that our intuitions regarding what can count as our counterparts are mostly in agreement. For instance, we'd all (I hope) agree that I can't have a counterpart that is, say, a desk. Lewis comments on a similarly absurd candidate for counterparthood: 'I suppose I might want to be a poached egg. (An ordinary poached egg - not an eggy creature that walks and talks). Would I then want to inhabit one of the worlds where I am a poached egg? That's not it. I take it that there are no such worlds. No poached egg is a counterpart of mine!' $(1979,530)$. 
non-concrete entities that don't postulate numerous spatio-temporally isolated worlds, all of which God must exist at. Rather, ersatz possible worlds are maximally consistent sets of propositions or simply ways that the world could be: we can therefore safely say that God's existence (given that His existence is necessary) is included in all of these sets. Sheehy proposes a way out for the genuine modal realist, which is that each world consists of a maximal set of spatio-temporally related objects and 'the domain of abstracta' (ibid., 319), which is atemporal and aspatial. If God exists as part of this domain, He could thus be timeless and necessary. However, Sheehy warns of the unparsimonious move of adding this extra domain into our ontology, whereas if God could straightforwardly exist 'at' a world we require just the one fundamental ontological category.

Nevertheless, Ross Cameron responds to Sheehy by arguing (as he claims Lewis would) that an atemporal God could exist 'at each world' in the sense that He exists from the standpoint of each world. Cameron uses Lewis's argument that pure sets such as numbers exist from the standpoint of every world, to argue that 'the theist should grant God the same status as pure sets have in this regard' $(2009,97)$, and this is sufficient to claim that God exists necessarily. Cameron cites Lewis's definition of existing from the standpoint of a world: it 'belongs to the least restricted domain that is normally... appropriate in evaluating the truth at that world of quantifications' (Lewis 1983b, 40). Cameron says that Lewis doesn't even claim that GMR gets rid of any commitment to abstracta anyway (Cameron 2009, 97), so it could be by belonging to this domain that God exists at every world. In fact, assigning God's existence to this alternative domain could even be argued for independently, on the basis that His existence ought to be entirely other than that of His creation. It's therefore quite fitting that God exists in a different way from all else. Importantly, though, God needs to be the only member of this domain, lest He be considered in the same ontological category as something else - say, numbers. If numbers exist from the standpoint of every possible world, it must be in a less fundamental way than God, because everything depends upon Him for its existence, and He's the source of all. ${ }^{20}$

${ }^{20}$ Alternatively, one might not consider the necessity of abstracta such as numbers to be a threat to God's creative power. Scott Shalkowski argues that 'if there are abstract objects and if they are the necessary existents that ground necessities, then it not only makes no sense to suggest that God somehow explains them, it is also unnecessary to think that any 'limits' they impose upon God threaten divine supremacy and majesty' $(2014,153)$. This is because these just are necessary: there's nothing beyond them that God can't do, for the only things that lie beyond them are those that are impossible. It might not even be such a problem, therefore, if we posit the existence of numbers as strictly necessary in such a way that they don't rely on God for their existence. We can argue that they remain no threat to God's majesty and power. 
Cameron has thus given the atemporalist the resources to explain God's necessity in terms of existence 'at' all modal realist worlds, by appealing to the standpoint relation. Presumably, people in other possible worlds can also be world-mates with this very same (timeless) God in this manner, without needing to exhibit spatio-temporal relations to Him. ${ }^{21}$ Assuming GMR, we can contend that the God who exists from the standpoint of each world is one and the same God across all worlds. Cameron says that 'counterpart theory is unmotivated for objects that have their intrinsic properties essentially' (2009, 99). God can't be God without possessing all of the intrinsic properties that He does, and so there arises no potential conflict between His different intrinsic properties at different worlds. ${ }^{22}$ I therefore maintain that atemporalists have the resources to respond to Sheehy's worry. They can consistently be modal realists and maintain that a timeless God is necessary. He (the very same God) exists at every possible world, because He exists from the standpoint of every possible world.

\subsection{Worlds apart: which ones do we consider?}

Returning, then, to Leftow's claim, it could be argued that genuine modal realists are in a better position to uphold it than ersatzists. Genuine modal realists think that every possible way that the world can consistently be concretely exists, and could thus maintain that many worlds with far less sin than our own are indeed actual. They could claim, in line with Leftow, that we do get modal variation if we stop restricting our attention to possible worlds with as much, or more sin than ours. After all, just one possible world where the Son isn't incarnate would be sufficient to yield modal variation and make true the claim that the timeless Son becomes incarnate. It could be argued that there are worlds with far less sin than ours (from the standpoint of which the Son still exists), and at these worlds He doesn't even need to consider

21 There's a further motivation for these relations that we exhibit to God not being spatiotemporal: if everyone in the multiverse bears any sort of spatiotemporal relation to the very same God, we're in danger of all worlds collapsing into one, simply in virtue of these connecting relations.

22 An anonymous referee worries that, if existing from the standpoint of all worlds is to belong to the domain of abstracta, then we have a difference between typical members of this domain (such as numbers) and God-in that typical abstracta do not have causal power, whereas God does. In turn, this causal relation between God and all worlds could in fact lead to modal collapse - as in the footnote above. However, I would maintain that a timeless God's causal power is not spatial or temporal, and it is only by virtue of causation typically being spatiotemporal that means it would lead to modal collapse if it existed between worlds. 
incarnating. This is because humanity is already in a fulfilled and loving relationship with God, and there's very little (if any) sin. If we were to consider these (concretely existing) worlds, then Leftow's modal claim goes through and we can make sense of 'becoming' incarnate in terms of modal variation. However, it seems that in this situation Leftow's modal claim is too weak. This is because we're no longer restricting our attention to the relevantly similar possible worlds that are sufficient to generate a substantial sense in which the Son 'could have refrained' from being incarnate. I explained this in section 2, and it's for this reason that the genuine modal realist, to the extent that she widens her scope to the worlds with very little sin, is diminishing the strength of Leftow's modal claim. On top of this, there's a further worry that lies waiting in the wings if we adopt GMR. I'll now illustrate it, strengthening my argument against Leftow.

\subsection{A Further Worry for Modal Realists}

The incarnation, according to Christianity, is unique in that it had never happened before and will never happen again: the Son's becoming flesh was enough to atone for the sins of all humanity for the rest of time. Let's call this the 'uniqueness requirement'. ${ }^{23}$ It's evidently central to Christianity, and a claim that must be upheld in line with orthodoxy. If one interprets Leftow's modal argument as a genuine modal realist would, then one faces the additional worry that the uniqueness requirement is flouted.

Given that all possible worlds concretely exist on GMR, just one such otherworldly incarnation is all that we need to be in violation of the uniqueness requirement. Put differently, the contingency that we desire from Leftow's modal claim is that there's no other world at which the Word takes on flesh. Ersatzists, importantly, don't face such worries, because they hold that only one world in fact obtains, so only one incarnation concretely exists. ${ }^{24}$ If we're genuine modal realists, assuming that God is omnibenevolent and that there exist worlds as sinful as our own, it emerges that we can't help but breach the uniqueness requirement. This is really no surprise, given that violating it is surely easier to do than it is to endorse incarnations in all relevantly similar possible worlds. This unwelcome outcome is an additional reason why GMR isn't congruous with Leftow's modal claim.

${ }^{23}$ See also the fifth ecumenical council, where the uniqueness requirement is endorsed (Price 2009).

${ }^{24}$ Unless, of course, there are multiple incarnations within a world, but this isn't something that I'm examining here. 
One potential line of response here is that the incarnation is unique according to GMR, because the Son's incarnation in our world was enough to atone everybody in every other possible world. Timothy O'Connor and Phillip Woodward suggest a view in this vicinity:

Human persons vary considerably, yet God's incarnation as the particular firstcentury Palestinian man Jesus of Nazareth is thought to serve God's restorative and identifying purposes for all of us. Why not for all [divine image-bearing] creatures human and non-human alike? $(2015,231)$

Here, the authors are suggesting that God's incarnation as Jesus in our world could be powerful enough to atone every species made in God's image, for the rest of time. In fact, it could be added that it's down-playing the significance of the incarnation to assume that the Son's sacrifice couldn't accomplish such a task. If this were the case, the argument could be applied across logical space as a whole to argue that we don't require incarnations in worlds with as much or more sin than our own, and so we can make sense of cross-worldly variation regarding the incarnation. However, there are several reasons to find this problematic, which $\mathrm{O}^{\prime}$ Connor and Woodward are themselves aware of. Firstly, it seems presumptuous to suppose that we humans have 'won an incarnational lottery' (ibid.), because there seems to be no reason why God would choose to be incarnate as one of us over being a human in a different world, or a member of a different species in any world. Moreover, the authors question how creatures in other (spatio-temporally discrete) worlds could know that their sins have been redeemed (ibid., 231-2). This leads to the related worry that these other-worldly creatures won't feel the comfort and hope that we in our world feel in our awareness of this knowledge.

Nevertheless, one might respond that the incarnation is still a unique event even if it happens at other worlds, because it only happens elsewhere in the sense that its counterparts happen. Each of these counterpart incarnations are brought about by the Son, who we've seen exists from the standpoint of every possible world. Furthermore, the other worlds where incarnations take place are all and only those in a similar state to our own regarding amounts of sin, and where the person who is incarnate is sufficiently similar to Jesus to be His counterpart, at a sufficiently similar period of history.

The problem here is that to the extent that we embrace $G M R$, we must also embrace an increase in number in these incarnations, given that the otherworldly incarnations are all real. More forcefully, given the spatio-temporal separation of worlds, Christ incarnate must differ at each one. ${ }^{25}$ This is supported

${ }^{25}$ With the exception of potential qualitatively identical worlds. 
by Cameron. We've seen he says that, just as unchanging objects don't face the problem of temporary intrinsics, 'counterpart theory is unmotivated for objects that have their intrinsic properties essentially' $(2009,99)$. For entities belonging to the latter category, such as the Son, we have:

...no problem in holding that [they] strictly and literally [exist] at more than one world. There will never arise a potential conflict with Leibniz's law, since there will never be one world at which [the object] is intrinsically $\mathrm{F}$ and another at which [it] is intrinsically not-F (ibid., 99-100).

In contrast, when we consider the incarnate Son, we evidently want to say that His actions (although all perfectly good) vary across worlds in response to the different events and circumstances there. The uniqueness requirement thus remains flouted, because different divine incarnations concretely exist in different possible worlds. Christ incarnate is a temporal, mutable being, and so $\mathrm{He}^{\prime} \mathrm{ll}$ possess different intrinsic properties at different times. Moreover, it's also important to hold that Christ incarnate differs across worlds simply because of the spatio-temporal separation of worlds. If the very same temporal, mutable being was able to exist within different spatio-temporally separated worlds, then these worlds would not in fact be spatio-temporally separated. Rather, they'd be parts of the very same world. It is, after all, part of the definition of genuine modal realist worlds that they're unified by their parts being spatiotemporally related, and by their spatio-temporal separation from other worlds and their parts. These are important reasons as to why Christ incarnate can't enjoy trans-world identity. ${ }^{26}$

Cashing out the claim that the timeless Son of God 'becomes' incarnate due to variation across genuine modal realist worlds therefore leads to us being unable to make sense of any cross-worldly variation regarding the incarnation. This is because at all of the relevantly similar worlds to our own, the Son is incarnate, so we end up endorsing multiple incarnations. A further problematic consequence of a genuine modal realist's interpretation of Leftow's claim is that we violate the all-important uniqueness requirement that's central to a Christian understanding of the incarnation. After making his modal claim, Leftow argues that the ball is in his opponent's court, and that they must provide an account of why modal variation isn't a sufficient explanation of the Son

${ }^{26}$ A further issue suggests itself here: how can Christ incarnate be identical with the Son of God, as must be the case according to orthodoxy? If many different counterparts of Christ are all identical with the very same Son who possess trans-world identity, then does this mean that all worlds collapse into one? Alternatively, how does one and the same being (the Son, and the various counterparts of Christ) exist both from the standpoint of every possible world, and in just one possible world? 
becoming incarnate. I've engaged in debate in response to Leftow's challenge, arguing that Leftow's modal claim doesn't achieve cross-worldly variation regarding incarnations, and that his account results in further problems besides.

\section{Conclusion}

I've argued in this section that there's no clear sense in which the Word taking on flesh varies across worlds, so atemporalists can't appeal to modal variation as a way that the Son becomes incarnate. Furthermore, Leftow's claim undermines the libertarian freedom of the Son, which is a result that Leftow himself would clearly be unhappy with. I explained that it's possible to adopt a compatibilist account of God's freedom here, in order to maintain that the Son is still free, but I anticipated that most Christians (including Leftow himself) wouldn't find this option desirable. I also illustrated a further unwelcome result of adopting GMR: we end up violating the all-important uniqueness requirement of the incarnation. I therefore conclude that if God is atemporal, there are great tensions with understanding the Son 'becoming' incarnate in terms of mere modal variation. The modal account only seems workable if we dispense with (or possibly re-work our understanding of) God's libertarian freedom. For now, though, I bat the ball back to Leftow's side of the net: the atemporalist needs a better account of how the Son of God became human. ${ }^{27}$

\section{Bibliography}

Adams, Robert Merrihew. 1972. "Must God Create the Best?" The Philosophical Review 81, 3: 317-332. https://doi.org/10.2307/2184329.

Almeida, Michael J. 2011. "Theistic Modal Realism?" In Oxford Studies in Philosophy of Religion, edited by Jonathan L. Kvanvig, 1-15. Oxford: Oxford University Press. https://doi.org/10.1093/acprof:oso/9780199603213.003.0001.

Beebee, Helen. 2003. "Local Miracle Compatibilism." Nô̂s 37, 2: 258-277. https://doi.org/10.1111/1468-0068.00438.

Cameron, Ross. 2009. "God exists at Every (Modal Realist) World: Response to Sheehy." Religious Studies 45, 1: 95-100. https://doi.org/10.1017/S0034412508009827.

27 Thank you to Mikel Burley and Helen Steward, who read and tirelessly provided helpful comments on many versions of this paper. Thanks also to Dani Adams, Daniel Molto and Jon Robson for their comments. I'm very grateful to audiences at the $4^{\text {th }}$ biennial Glasgow Philosophy of Religion Seminar, the Leeds Centre for Philosophy of Religion (in particular, to Mark Wynn) and the Leeds Postgraduate Philosophy Seminar-where I received invaluable comments on this paper in talk-form. Thank you also to two anonymous referees for TheoLogica for your most helpful and careful comments. Finally, the biggest thanks are to Adina Covaci. 
Diekemper, Joseph. 2012. “Eternity, Knowledge, and Freedom." Religious Studies 49, 1: 45-64. https://doi.org/10.1017/S0034412512000170.

Hill, Jonathan. 2012. "Incarnation, Timelessness, and Exaltation." Faith and Philosophy 29, 1: 3-29. https://doi.org/10.5840/faithphil20122911.

Kelly, J. N. D (ed.). 2006. “The Creed of Nicaea." In Early Christian Creeds, edited by J.N.D. Kelly, 205-230. New York: Longman.

Leftow, Brian. 2002. "A Timeless God Incarnate." In The Incarnation: An Interdisciplinary Symposium on the Incarnation of the Son of God, edited by Stephen T. Davis, Daniel Kendall and Gerald O' Collins, 273-299. Oxford: Oxford University Press. https://doi.org/10.1093/0199248451.003.0012.

Leftow, Brian. 2016. "Divine Simplicity and Divine Freedom." Proceedings of the ACPA 89: 45-56.

Leftow, Brian. 2017. "Two Pictures of Divine Choice." In Free Will and Classical Theism, edited by Hugh McCann, 152-172. Oxford: Oxford University Press. https://doi.org/10.1093/acprof:oso/9780190611200.003.0009.

Leftow, Brian. Forthcoming. "Divine Freedom." In The Wiley Companion to Free Will, edited by Joseph Campbell. Oxford: Wiley-Blackwell.

Lewis, David. 1968. "Counterpart Theory and Quantified Modal Logic." The Journal of Philosophy 65, 5: 113-126. https://doi.org/10.2307/2024555.

Lewis, David. 1979. "Attitudes De Dicto and De Se." The Philosophical Review 88, 4: 513-543. https://doi.org/10.2307/2184843.

Lewis, David. 1981. "Are we free to break the laws?" Theoria 47, 3: 122-29. https://doi.org/10.1111/j.1755-2567.1981.tb00473.x.

Lewis, David. 1983. "Postscripts to 'Counterpart theory and quantified modal logic," 39-40. In his Philosophical Papers Volume 1, 39-46. Oxford: Oxford University Press.

Lewis, David. 1986. On the Plurality of Worlds. Oxford: Blackwell.

Marmodoro, Anna and Hill, Jonathan. 2010. "Compositional models of the Incarnation: unity and unifying relations." Religious Studies 46, 4: 469-488. https://doi.org/10.1017/S0034412510000119.

Mullins, R. T. 2016. The End of the Timeless God. Oxford: Oxford University Press. https://doi.org/10.1093/acprof:oso/9780198755180.001.0001.

Price, Richard. 2009. The Acts of the Council of Constantinople of 553 with Related Texts on the Three Chapters Controversy, Volume 1. Liverpool: Liverpool University Press. https://doi.org/10.3828/978-1-84631-178-9.

O'Connor, Timothy and Woodward, Phillip. 2015. "Incarnation and the Multiverse." In God and the Multiverse, edited by Klaas J. Kraay, 227-241. London \& New York: Routledge.

Rowe, William. 2004. Can God Be Free? Oxford: Clarendon Press.

Rowe, William and Howard-Snyder, Frances. "Divine Freedom." In The Stanford Encyclopedia of Philosophy, edited by Edward N. Zalta. Fall 2008 
Edition. http://plato.stanford.edu/archives/fall2008/entries/divine-freedom/ (accessed 11/04/16).

Senor, Thomas D. 1990. "Incarnation and Timelessness." Faith and Philosophy 7, 2: 149-164. https://doi.org/10.1017/S0034412506008419.

Shalkowski, Scott. 2014. "God with or without abstract objects." In Beyond the Control of God? Six Views on the Problem of God and Abstract Objects, edited by Paul M. Gould, 143-154. London: Bloomsbury.

Sheehy, Paul. 2006. "Theism and Modal Realism." Religious Studies 42, 3: 315328. https://doi.org/10.1017/S0034412506008419.

Steward, Helen. 2015. "Agency Incompatibilism and Divine Agency." European Journal for Philosophy of Religion 7, 3: 67-78. https://doi.org/10.24204/ejpr.v7i3.105.

Talbott, Thomas. 2009. "God, Freedom, and Human Agency." Faith and Philosophy 26, 4: 376-395. https://doi.org/10.5840/faithphil200926436.

Published Online: January 17, 2019 